\title{
Serbest Mitokondriyal DNA'nın Sistemik Dolaşımdaki Rolü ve Hastalıkların Patogenezine Etkisi
}

\author{
Ayşe Tülay Aydınoğlu@ $\odot$, Evrim Aksu Mengeş@, Burcu Balcı Hayta $\odot$
}

Hacettepe Üniversitesi Tıp Fakültesi, Tıbbi Biyoloji Anabilim Dalı, Ankara, Türkiye

Ayşe Tülay Aydınoğlu

Evrim Aksu Mengeş, MSc

Burcu Balcı Hayta, Doç.Dr

İletişim:

Doç. Dr. Burcu Balı Hayta Hacettepe Üniversitesi Tıp Fakültesi, Tıbbi Biyoloji Anabilim Dalı, Ankara, Türkiye Tel: +903123052541

E-Posta: burcub@hacettepe.edu.tr

Gönderilme Tarihi : 01 Kasım 2018

Revizyon Tarihi : 10 Aralık 2018

Kabul Tarihi $\quad$ : 18 Aralık 2018

\section{ÖZET}

Mitokondri, oksidatif fosforilasyon ile ATP üretiminin yanı sıra üstlendiği görevler ile hücre canlılı̆ı̆ın sürdürülebilmesinde merkezi öneme sahip çok işlevli bir organeldir. Organelin hücre canlılı̆ına katkıda bulunmasında rol oynayan en temel özelliklerinden biri de kendine özgül genetik sistemidir. Mitokondriyal DNA (mtDNA)'nın normal fizyolojik koşullarda organelin matriks kısmında bulunduğu, fakat gerek organel gerekse hücre hasarı olduğu durumda hücre dışı matrise salınarak serbest dolaşıma katıldığı belirtilmiştir. Özellikle son yıllarda mtDNA'ya ilişkin yapılan çalışmalar, organel genomunun dolaşımda üstlendiği roller ve hastalıklarla ilişkisi üzerine yoğunlaşmıştır. Sistemik dolaşımda serbest halde bulunan mtDNA'lar [circulating cell free mtDNA (ccf-mtDNA)] bağışıklık sisteminde görevli Kalıp Tanıma Reseptörleri [Pattern Recognition Receptors (PRRs)] tarafından Hasarla İlişkili Moleküler Yapılar [Damage Associated Molecular Patterns (DAMPS)] olarak algılanarak pro-inflamatuar yanıt oluşumunda temel bir rol üstlenmektedir. Bu derlemede, ccf-mtDNA'nın sistemik dolaşıma katılma mekanizmaları ve etkileşimde bulunduğu yolakların detayına inilerek, bağışıklık sisteminin bir uyaranı olarak görev almasına ve hastalıklarla ilişkisine dair bilgiler özetlenmiştir.

Anahtar sözcükler: ccf-mtDNA, sistemik dolaşım, inflamasyon

THE ROLE OF CIRCULATING CELL-FREE MITOCHONDRIAL DNA IN SYSTEMIC CIRCULATION AND ITS EFFECT ON DISEASES PATHOGENESIS

\section{ABSTRACT}

Mitochondria are multi-functional organelles with many essential roles in the maintenance of cell viability as well as ATP production by oxidative phosphorylation. One of the most important features of this organelle that contributes to cell viability is its own genetic system. Mitochondrial DNA (mtDNA), which is located in the mitochondrial matrix under normal physiological conditions, is released into the extracellular matrix and enters the systemic circulation in case of an organelle and/or a cellular damage. Recent studies have focused on the role of mtDNA in circulation and its association with diseases. Circulating cell-free mtDNA (ccf-mtDNA) is regarded as a Damage Associated Molecular Pattern (DAMP) and recognised by the Pattern Recognition Receptors (PRRs). They play a fundamental role in initiating the pro-inflammatory response. In this review, the mechanisms of ccf-mtDNA-induced inflammatory pathways in systemic circulation and the effect of ccf-mtDNA on diseases pathogenesis will be discussed.

Keywords: ccf-mtDNA, systemic circulation, inflammation

\section{Mitokondri}

Evrimsel geçmişi yaklaşık iki milyon yıl önce bir alfa-proteobakteriye dayanan ve ökaryotik hücrelerin tamamında bulunan mitokondri, kendine özgül genetik sistem içeren yarı-özerk bir organel olmakla birlikte, hücre içinde dinamik bir yapı 
sergilemektedir. Temelde hücresel metabolik faaliyetlerin devamı için gerekli ATP üretiminden sorumlu olmakla birlikte, hücre içi $\mathrm{Ca}^{+2}$ dengesinin korunması, demir (Fe) - sülfür (S) biyogenezi, apoptoz, nükleotit, aminoasit ve lipit metabolizması gibi birçok hücresel aktivitede rol aldığı bilinmektedir $(1,2)$. Yüksek miktarda organel stresine ve genom hasarına maruz kalan bu organelin işlevsel ve yapısal bütünlüğü; katlanmamış protein cevabı (UPRmt), biyogenez, mitokondriyal füzyon ve fisyon, mitofaji gibi birçok farklı mitokondriyal kalite kontrol mekanizmasının koordineli bir şekilde çalışması ile kontrol edilmektedir (3). Gelişmekte olan genombilim teknolojileri, birçok hastalığın başlangıcı ve ilerlemesinin altında yatan temel nedenlerden birinin de; hücresel stres artışına bağlı olarak mitokondriyal kalite kontrol mekanizmalarının işlevini doğru olarak yerine getirememesi ve organelin işlevini yitirmesi olduğunu ortaya koymaktadır (4). Organelde meydana gelen işlev kaybının kanser, kardiyovasküler hastalıklar, diyabet ve nörodejeneratif hastalıklar gibi birçok farklı patolojik durum ile ilişkisi olduğu bilinmektedir (5).

Hücre canlılığı ve ölümü için temel işlevleri olan bu organelin, bilinen işlevlerini korumaya ve hücre içerisinde farkIı mekanizmalardaki rollerini aydınlatmaya yönelik birçok bilimsel çalışma yapılmaktadır. Bu çalışmalar sayesinde, her geçen gün organelin hücre içerisindeki bilinmeyen işlevlerine ilişkin edinilen bilgiler artmakta ve yeni araştırma alanları doğmaktadır. Özellikle 2010 yıından bu yana ağırlık kazanmış olarak, mitokondrinin çeşitli sinyal yolaklarına eşlik ederek inflamasyon aracılığıyla doğal bağışıklık sistemini harekete geçirmede anahtar rol oynadığı ortaya çıkmıştır $(2,6,7)$.

\section{Mitokondriyal DNA (mtDNA)}

Çift zincirli ve halkasal yapıda olan mtDNA, 16.569 baz çifti (bç) uzunluğunda olup 37 gen içermekte ve yaklaşık 1200 kadar proteinden oluşan mitokondriyal proteomun yalnızca \%1'ini kodlamaktadır. Elektron transport zinciri (ETZ)'nde görevli temel proteinlerin yanısıra, ATP sentaz enziminin bazı alt üniteleri olacak şekilde toplam 13 polipeptit ve mitokondriye özgül 22 tRNA ve 2 rRNA sentezinden sorumludur (8). Mitokondriyal proteomun $\% 99$ 'u ise nükleer DNA (nDNA) tarafından kodlanmakta ve translasyon sonrasında translokaz proteinleri yardımıyla sitozolden mitokondriye taşınmaktadır (9).

Memeli somatik hücrelerinde bulunan mitokondri sayısı 80-2000 (10) arasında değişmekle birlikte, organelde bulunan mtDNA kopya sayısı da değişkenlik göstermektedir. Kas, sinir, karaciğer gibi enerji intiyacı fazla olan hücrelerde fazla sayıda olacak şekilde mitokondri başına düşen mtDNA sayısı 2-10 civarındadır (11). Organel genomunun kopya sayısı, hücresel veya çevresel streslere cevap olarak değişkenlik gösterebilmektedir (12). Birçok hücre ve dokuda mtDNA miktarının oksidatif fosforilasyonun devamlılığı için gerekli olandan fazla bulunmasının, mtDNA'nın sinyal iletimi ve/veya bağışıklık sistemindeki olası işlevleriyle ilişkili olabileceği belirtilmiş̧ir (7).

mtDNA'da meydana gelen mutasyonlar oksidatif fosforilasyon ile enerji üretimini sekteye uğratarak reaktif oksijen türlerinin (ROS) aşırı üretimi, oksidadif stres, hücre ölümü gibi durumlarla sonuçlanarak birçok hastalığın patogenezinde etkin rol oynamaktadır (13). nDNA'dan farklı olarak mDNA'da intronların olmayışı genomu yapısal olarak daha kompakt bir hale getirmekle birlikte, histon proteinlerinin eksikliğinin organel genomundaki mutasyon hızını arttırdığı öne sürülmüştür (8). Ancak yapılan araştırmalarda, histon proteinleri olmasa da mtDNA'nın tamamen çıplak yapıda olmadığı, mitokondriyal transkripsiyon faktör A (TFAM) proteininin temel bileşeni olduğu protein-DNA kompleksleri (nükleoid) şeklinde paketli halde bulunduğu tespit edilmiştir (12). Buna rağmen, nDNA için var olan birçok gelişmiş tamir mekanizmasının mtDNA'da olmaması sebebiyle, organel genomunun mutasyon birikimine açık olduğu bilinmektedir (14). Buna ek olarak, mitokondride gerçekleşen ROS üretimine bağlı oksidatif stres kaynaklı hasar mtDNA'nın nDNA'ya kıyasla mutasyonlara daha açık olmasının altında yatan temel etken olarak gösterilmektedir. Ayrıca, lipofilik katyon yapısındaki tedavi ajanlarının, mitokondri iç zarındaki negatif zar potansiyeli nedeniyle mitokondri içinde birikmesi de, organeli hasara açık hale getirmektedir (15). Negatif iç zar potansiyeli sebebiyle yüksek miktarda lipofil katyon mitokondri içerisine alınmakta ve burada birikebilmektedir (16). Tedavi amaçlı kullanılan lipofilik katyon yapıdaki bazı kimyasallar da mitokondride birikip mtDNA hasarına sebep olabilmektedir (17).

Mitokondrinin bakteriden köken alması sebebiyle, mtDNA'da bakteri genomuna benzer nitelikte hipometile CpG motifleri bulunduğu; buna karşın memeli nDNA'sının yaygın olarak metile olmuş $\mathrm{CpG}$ motifleri içerdiği bulunmuştur. İki genom arasında bulunan bu farkın, mtDNA'nın yabancı bir DNA molekülü olarak tanınmasına yol açarak bağışıklık sistemini uyardığı ifade edilmektedir $(18,19)$. mtDNA'daki metilasyon oranını anlamak üzere memeliler üzerinde farklı araştırmalar yapılmıştır. 2013 yılında insan hücre hatları ve kan örnekleri üzerinde yapılan bir araştırmada, mtDNA'daki CpG adacıklarında metilasyon olmadığı sonucuna ulaşılırken, aynı sene içerisinde yapılmış bir başka araştırmada gerek insan gerekse fare kökenli hücre 
hatları ve primer kültür örneklerinde mtDNA'da metillenmiş CpG adacıkları tespit edilmiştir (20,21). 2016 yılında ise insan mtDNA'sında metillenmiş CpG adacıklarının varlığı bir başka çalışma grubu tarafından da desteklenmiştir (22). Ancak, 2017 yllına ait bir derlemede mtDNA'da metilasyon varlığının netlik kazanması yönündeki araştırmaların önemine vurgu yapılırken, mtDNA'nın metilasyon seviyesinin düşük veya yüksek olmasının bağışıklık sistemini uyarması yönünde bir etki yaratmadığı ileri sürülmüștür (7).

\section{Serbest mtDNA (ccf-mtDNA) ve Sistemik Dolaşımdaki Rolü}

Normal fizyolojik koşullarda mitokondri matriksinde bulunan mtDNA'nın, bazı durumlarda organelden sitoplazmaya ve buradan da hücre dışı matrise sızarak kan, idrar, tükürük, eklem sıvısı, beyin-omurilik sıvısı gibi çeşitli vücut sıvılarına katıldığı daha önce yapılmış olan çeşitli çalışmalarda ifade edilmiştir (7,23-26). Vücut sıvılarında bulunan organel DNA'sl, serbest mtDNA (circulating cell-free mtDNA/ccf-mtDNA) olarak adlandırılmaktadır. Son yıllarda ccf-mtDNA'nın özellikle sistemik dolaşımda üstlendiği roller üzerine çok fazla sayıda araştırma yapılmaktadır.

mtDNA'nın sistemik dolaşıma çıkma mekanizması henüz net olarak bilinmese de, günümüze kadar yapılmış olan araştırmalarda salınıma sebep olan birçok farklı fizyolojik durum ortaya konmuştur. Dolaşımdaki mtDNA'nın kaynağı doku hasarından etkilenen hücreler veya inflamatuvar mekanizmalarda görevli olan çeşitli hücreler olabilir. Zhang ve arkadaşlarının yaptığı bir çalışmada, travma ve hemorajik şok sonrası dokuda meydana gelen hasara bağIı olarak hücre yapısının ve mitokondrilerin zarar görmesi sebebiyle mtDNA'nın dolaşıma salındığı belirlenmiştir. Hücresel hasar ve/veya nekroz sonucunda, hasarlı mitokondrilerden hücre dışı matrise $\mathrm{N}$-formilpeptit, TFAM gibi moleküllerin salınımının yanı sıra, mtDNA salınımı da gerçekleşmektedir $(2,27)$. Ayrıca, mitokondri morfolojisi ve dinamiğinde meydana gelen değişimlerin ve mitokondriyal strese bağlı organel hasarının da mtDNA'nın sistemik dolaşıma salınma sebepleri arasında sayıldığı bilinmektedir (2). Bu mekanizmaların yanı sıra, makrofajlar üzerinde yapılmış bir çalışmada otofaji mekanizmasında görev alan proteinlerin eksikliğinde de sitozole mtDNA salınımının gerçekleştiği gösterilmiştir (28). Farklı bir çalışmada ilginç bir bulgu olarak, apoptoz sırasında BCL-2 like protein 4 (BAX) ve BCL-2 homologous antagonist/killer (BAK) aracılı mitokondri dış zar geçirgenliğinin artması nedeniyle sitoplazmaya çıkan iç zardan mtDNA'nın salındığı tespit edilmiştir (29). Yapılan bir başka araştırmada ise, dokuda hasarın oluştuğu bölgeye göç eden polimorfonükleer lökositler (PMN), trombositler ve kök hücreler tarafından da nekroz durumundan bağımsız şekilde sekonder olarak mtDNA aktif salınımının gerçekleşme olasııı̆ından bahsedilmiştir (30). Sağlıklı bireylerden elde edilen örneklerde de ccf-mtDNA'nın varlığının gösterilmesi, mtDNA'nın normal fizyolojik durumda da düzenli olarak sitoplazmaya geçerek hücre dışı matrise ve buradan da sistemik dolaşıma katılmasına yol açan bir mekanizmanın var olabileceğini düşündürmektedir $(7,31)$.

ccf-mtDNA'nın çift zincirli uzun ve kısa fragmanlar halinde serbest olarak veya boyutları birbirinden farklı mikropartiküller içerisinde dolaşıma katıldığı bilinmektedir $(7,32,33)$. Doku hasarının devamındaki nekroz sürecinde fragmanlar halinde pasif taşıma ile dolaşıma katılırken; inflamatuvar cevapta görevli hücrelerden ise aktif taşıma aracılığıla mikropartiküller içerisinde salındığı gösterilmiştir $(34,35)$. mtDNA'nın fragmantasyon mekanizması tam olarak bilinmese de, yapılan çalışmalarla serbest radikaller tarafından indüklenen oksidatif stresin organel DNA'sının hidrolizine neden olduğu gösterilmiştir (36). Mitokondriyal stres ve/ veya apoptoz sırasında mitokondri permeabilite geçişi (MPT) porlarının açılmasıyla 700 bç. uzunluğa kadar lineer mtDNA fragmanlarının organelden dışarı çıkabildiği saptanmıştır $(37,38)$. Bunun yanı sıra, hasarlı mitokondrinin mitofaji aracılığıyla ortadan kaldıralamadığı durumlarda ise hücre homeostazının korunması amacıyla, sitozolde biriken okside haldeki mtDNA'nın mikropartiküllerce paketlenerek hücreden uzaklaştırıldığı düşünülmektedir $(30,35,39)$.

Gerek serbest halde, gerekse mikropartiküller içinde olsun, ccf-mtDNA doğal bağışıklık sistemi tarafından tanınan kuvvetli bir tehlike sinyali olup inflamatuar cevabı ayarlamada önemli bir işleve sahiptir. ccf-mtDNA'nın sistemik inflamasyon ve mitokondriyal hasar arasındaki bağlantıda merkezi rol üstlenebileceği gösterilmiştir (40). Doku hasarı sonrasında hücrelerden sızarak dolaşıma katılan ve doğal bağışıklık sistemini uyaran moleküller Hasarla İlişkili Moleküler Yapılar [Damage Associated Molecular Patterns (DAMPs)] olarak adlandırılmaktadır. Hücresel strese bağlı olarak mitokondriyal kalite kontrol mekanizmalarının başarısız olduğu durumda, ayrıca apoptotik ve nekrotik hücre ölümlerinde, hücreden dışarı çıkarak sistemik dolaşıma çıkan ccf-mtDNA'nın DAMP olarak görev aldığı bilinmektedir $(6,32,41)$. ccf-mtDNA, içerdiği hipometile CpG motifleri ile, membrana bağlı ya da sitoplazmik DNA sensörleri olan ve patojen ilişkili cevapta görev alan Kalıp Tanıma Reseptörleri [Pattern Recognition Receptors (PRRs)]'ne bağlanarak inflamatuar cevabı aktive ederler (27). Bu yolakta görevli PRR reseptörleri; Toll-like 
reseptör (TLR), Nucleotide-binding oligomerization domain-Like reseptör (NLR) ve sitozolik cyclic GMP-AMP synthase-stimulator of interferon genes (cGAS-STING) olmakla beraber, üzerinde en çok çalışıımış olan yolak TLR9 aracılı olandır (42).

Dokuda gelişen patolojiye bağlı olarak dolaşıma katılan ccf-mtDNA, lökositler içerisine internalize olur ve endolizozomal kompartmanda TLR9- myeloid differentiation primary response protein 88 (MYD88)- nuclear factor-KB (NF$\mathrm{KB}$ ) sinyal yolağını uyarır. Bu yolak, tumour necrosis factor (TNF), interleukin (IL)-6, interleukin (IL)-8 ve adhezyon molekülleri gibi pro-inflamatuar aracıların üretimini artırarak lökosit farklılaşmasına ve dokuya sızmasına sebep olur ve patolojinin gelişmiş olduğu doku hücrelerinde inflamazom oluşumunu tetikler (Şekil 1) Bunun yanı sıra, hücreden salınan mikropartiküller içindeki ccf-mtDNA'nın da dokuda dinlenme halinde bulunan makrofajlardaki TLR9 tarafından tanınarak NFKB sinyal yolağı aktivasyonuyla pro-inflamatuvar yanıtı başlattığı gösterilmiştir (7). ccfmtDNA'nın TLR9 aracılı pro-inflamatuar cevap aktivasyonu hayvan modellerinde yapılan çalışmalarla da desteklenmiştir $(43,44)$. ccf-mtDNA dışında, oksidatif hasar içeren mtDNA'nın sitoplazmaya çıkmasının da Nod-like receptor family pyrin domain-containing 3 (NLRP3) inflamazomunun oluşumunda anahtar rol üstlendiği belirtilmiştir $(28,45)$. Oligomerize olan NLRP3 inflamazomu, adaptör bir protein olan Apoptosis-asociated speck like protein with a CARD (ASC) aracılığı ile kazpaz-1 ile etkileşime girerek IL-1 $\beta$ ve IL-18'in kesimini ve salınımını tetikler ve farklı bir yolakla daha inflamatuar cevabı aktive eder (Şekil 1) (7). Devamında, aktifleşen NLRP3 inflamazomunun pozitif geri besleme döngüsü ile daha çok ccf-mtDNA'nın dolaşıma çıkmasına sebep olduğu öne sürülmektedir (46).

TLR9 ve NLRP3 yolaklarına ek olarak mtDNA'nın aktive ettiği diğer bir yolak ise cGAS-STING yolağıdır. TFAM eksikliği ve çeşitli enfeksiyonların nükleoid kaybına sebep olarak mtDNA paketlenmesini/stabilitesini bozduğu ve mtDNA'nın fragmanlara ayrılmasına neden olarak bu yolağı aktive ettiği bilinmektedir (47). Sitozolik DNA sensörü olan cGAS, mitokondriden sitoplazmaya çıkmış olan

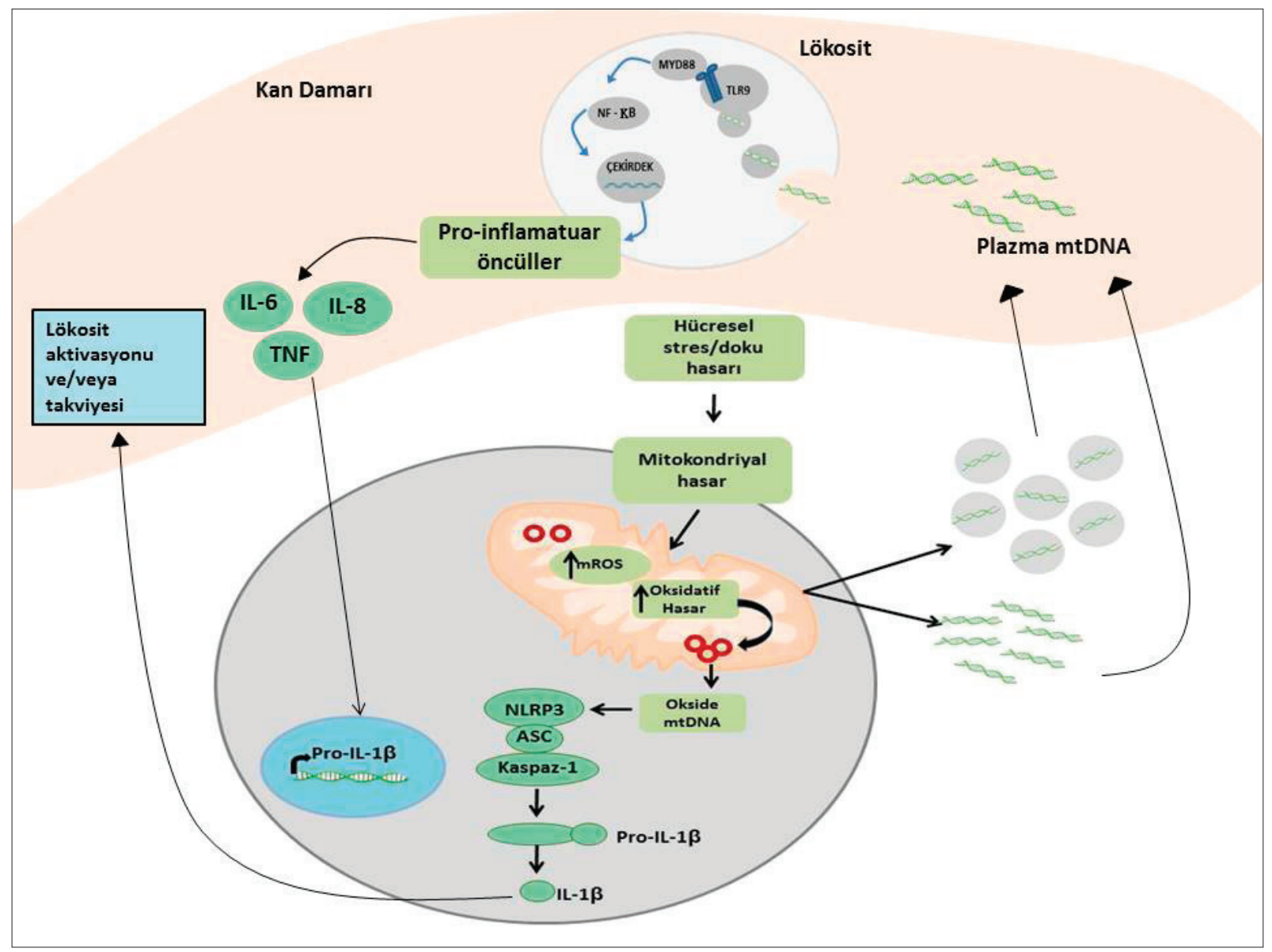

Şekil 1. Dolaşıma katılan ccf-mtDNA ve pro-inflamatuar yanıt oluşumundaki rolü (West ve Shadel, 2017'den uyarlanmıştır.) 
mtDNA fragmanlarının bağlanmasıyla aktive olur ve ikincil mesajcı olarak görev yapan cyclic GMP-AMP dinucleotide (cGAMP) sentezini katalizleyerek, endoplazmik retikulumda yerleşim gösteren STING'i aktive eder (48). Aktif STING, protein kinazlar aracılığı ile transkripsiyon faktörleri olan NF-kB ve Interferon Regulatory Factor 3 (IRF3)'ü aktive eder. Bu sayede, Tip 1 interferon (IFN1) ve Interferon-stimulated genes (ISG)'lerin ifadesiartar ve antiviral doğal bağışıklık sistemi harekete geçmiş olur (Şekil 2) (47). Ayrıca, apoptotik kaspazların inaktif olduğu mitokondri hasarı durumunda da BAX ve BAK aracılı mtDNA salınımının cGAS-STING yolağını uyardığı belirtilmiştir $(49,50)$. Bu çalışmalara ek olarak, aktif nötrofillerden salınan mtDNA'nın da cGASSTING yolağıyla etkileşimi bulunmaktadır $(35,51,52$,$) .$ Son yıllarda yapılan çalışmalarda Nötrofil ekstraselüler tuzak (NET) oluşumlarının mtDNA içerdiği saptanmış ve Sistemik lupus eritematozus (SLE) hastalarında NET aracılı salınmış olan ccf-mtDNA'nın IFN1 salınımını tetikleme potansiyeli olduğu öne sürülmüştür $(52,53)$. Bu nedenle, ccfmtDNA'nın benzer patolojik zemini olan diğer otoimmün hastalıklarda da rolü olabileceği düşünülmektedir (7).

\section{ccf- mtDNA ve Hastalıklarla İlişkisi}

Mitokondri, hücre içerisinde üstlendiği pek çok anahtar rolün yanı sıra, kendine özgül DNA'sı aracılığıyla çeşitli sinyal yolaklarını uyararak hastalıkların patogenezine etki etmektedir. Son yıllarda, sistemik dolaşıma katılan ccf-mtDNA'nın da, mitokondriyal hasar ve sistemik inflamasyon arasındaki bağlantıda merkezi bir rol üstlendiği ve birçok farklı hastalık grubunda doğal bağışıklık sisteminin agonisti olarak inflamatuar patolojiyi etkilediği saptanmıştır (Tablo 1). Bu nedenle, organel DNA'sının bir otopatojen olarak işlev gördüğü ve bağışıklık sistemininin uyaranı olduğu ileri sürülmektedir $(54,55)$. Birçok farklı hastalığın yanı sıra, enfeksiyonlardan bağımsız olarak yaşlanma sürecinde görülen kronik inflamasyon tablosunda da (inflammaging) ccf-mtDNA'nın DAMP olarak işlev gördüğü, dolayısı ile yaşlanma sürecinin otoimmün hastalık benzeri bir yolak olarak değerlendirilebileceği öne sürülmüştür (40). Ayrıca, ccf-mtDNA gibi dolaşımda serbest halde bulunan DNA'lar, hastalıkların erken tanısında doku biyopsilerine nazaran elde edilmesi daha kolay olan 'liquid biopsy"ler olarak işlev görebilmektedir (56). Birçok farklı kanser türünde, ccf-mtDNA'nın invaziv olmayan diyagnostik ve prognostik biyobelirteç olma potansiyeli ortaya çıkmıştır (57). Buna ek olarak, ccf-mtDNA miktarının kanser dışındaki farklı hastalıklarda da kontrol bireylere oranla istatistiksel olarak anlamlı ölçüde değişiklik göstermesi (Tablo 1), ccf-mtDNA'nın bu hastalıklarda da rutin tanı amaçlı kullanılabileceğini göstermiştir.
Tablo 1. Farklı hastallk gruplarına ait vücut sıvlarından elde edilen örneklerde ccf-mtDNA miktarındaki değişimler. (West \& Shadel 2017 ve

Boyapati vd., 2017'den uyarlanmışı̧ı.)

\begin{tabular}{|c|c|c|c|}
\hline $\begin{array}{l}\text { Hastalık } \\
\text { Kategorisi }\end{array}$ & Hastalık & $\begin{array}{l}\text { Analiz Edilen } \\
\text { Vücut SIVISI }\end{array}$ & $\begin{array}{l}\text { ccf-mtDNA } \\
\text { (artış/azalış) }\end{array}$ \\
\hline \multirow{2}{*}{$\begin{array}{l}\text { Otoimmün } \\
\text { Hastalıklar }\end{array}$} & $\begin{array}{l}\text { Romatoid ve Inflamatuar } \\
\text { Artrit }\end{array}$ & $\begin{array}{c}\text { Plazma, Eklem } \\
\text { Sivisı }\end{array}$ & Artış \\
\hline & Granülomatozisli polianjiitis & Serum & Artış \\
\hline \multirow{5}{*}{$\begin{array}{l}\text { Kardiyovasküler } \\
\text { Hastalıklar }\end{array}$} & Hipertansiyon & Plazma & Artış \\
\hline & Ateroskleroz & Plazma & Artış \\
\hline & Miyokard İnfarktüsü & Plazma & Artış \\
\hline & Koroner Kalp Hastalığı & Plazma & Artış \\
\hline & İskemik Kalp Hastalığı & Serum & Artış \\
\hline \multirow{3}{*}{$\begin{array}{l}\text { Karaciğer } \\
\text { Hastalıkları }\end{array}$} & Akut Karaciğer Yetmezliği & Serum & Artış \\
\hline & $\begin{array}{l}\text { Nonalkolik Steatohepatit } \\
\text { (NASH) }\end{array}$ & Plazma & Artış \\
\hline & $\begin{array}{l}\text { Asetaminofen Dozaşımına } \\
\text { Bağlı Olarak Gelişen } \\
\text { Karaciğer Yetmezliği }\end{array}$ & Serum & Artış \\
\hline \multirow{3}{*}{ Travma } & Travma & Plazma & Artış \\
\hline & $\begin{array}{l}\text { Sistemik Inflamatuvar Yanit } \\
\text { Sendromu (SIRS) }\end{array}$ & Plazma & Artış \\
\hline & $\begin{array}{l}\text { Çoklu Organ Yetmezliği } \\
\text { Sendromu (MODS) }\end{array}$ & Plazma & Artış \\
\hline Enfeksiyon & Sepsis & Plazma & Artış \\
\hline \multirow{10}{*}{ Kanser } & Meme Kanseri & Plazma & Azalış \\
\hline & Yumurtalık Kanseri & Plazma & Artış \\
\hline & Akciğer Kanseri & Plazma & Artış \\
\hline & Germ Hücreli Testis Kanseri & Serum & Artış \\
\hline & Ewing Sarkomu & Serum & Azalış \\
\hline & Prostat Kanseri & Plazma & Artış \\
\hline & Ürolojik malignite & Serum & Artış \\
\hline & Adenokarsinom & Plazma & Artış \\
\hline & Renal Hücreli Karsinom & Plazma & Artış \\
\hline & Hepatoselüler Karsinom & Serum & Azalış \\
\hline \multirow{2}{*}{$\begin{array}{l}\text { Nörodejeneratif } \\
\text { Hastalıklar }\end{array}$} & Alzheimer & $\begin{array}{l}\text { Beyin- Omurilik } \\
\text { SIVISI }\end{array}$ & Azalış \\
\hline & Parkinson & $\begin{array}{l}\text { Beyin-Omurilik } \\
\text { SIVISI }\end{array}$ & Azalış \\
\hline $\begin{array}{l}\text { Yaşlanma ile } \\
\text { İlişkili Hastalıklar }\end{array}$ & Kronik Inflamasyon & Plazma & Artış \\
\hline \multirow{7}{*}{ Diğer } & Otizm & Serum & Artış \\
\hline & Bipolar & Serum & Artış \\
\hline & $\begin{array}{l}\text { Hemodiyalize Bağlı Kronik } \\
\text { İnflamasyon }\end{array}$ & Plazma & Artış \\
\hline & Aşındıııcı Yaralanma & Plazma & Artış \\
\hline & Friedreich Ataksisi & Plazma & Azalış \\
\hline & Majör Depresif Bozukluk & Plazma & Artış \\
\hline & Egzersiz & Plazma & Azalış \\
\hline
\end{tabular}




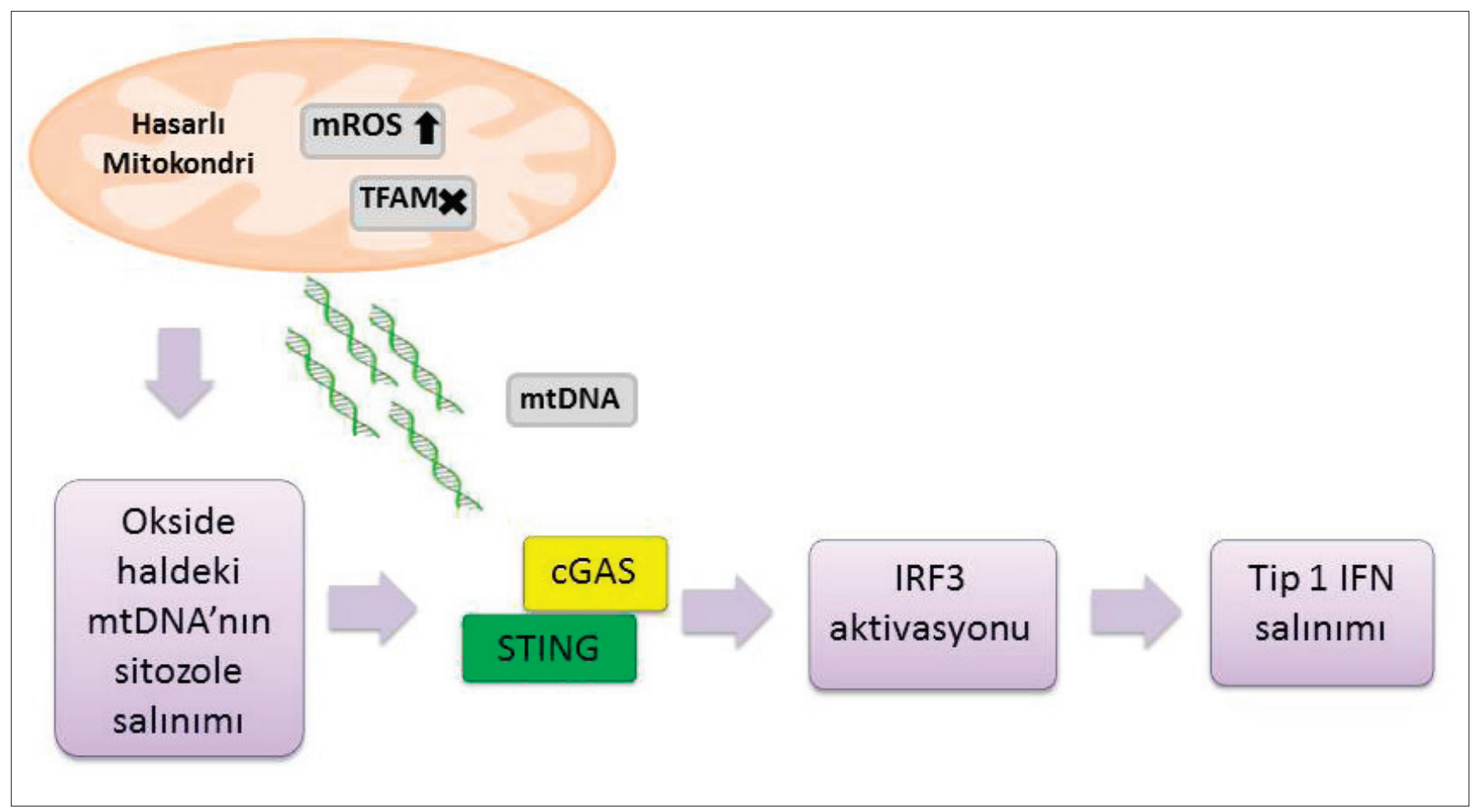

Şekil 2. Hasarı mtDNA tarafından cGAS-STING yolağının aktivasyonu ve immün cevabın oluşumu

Hastalıklarla ilişkili yapılan araştırmalar, ccf-mtDNA aracıIı inflamasyonun, farklı genetik ve çevresel kökenleri olan hastalık gruplarında ortak bir tedavi hedefi olma potansiyelini ortaya çıkarmış ve translasyonel bir yaklaşımla yeni tedavi stratejilerinin (sitozolik mtDNA salınımının önlenmesi, mitokondriyal kalite kontrol mekanizmalarının aktive edilmesi, mtDNA'nın inflamatuar potansiyelinin azaltılması, ccf-mtDNA aracılı inflamatuar yolağın aktivasyonunun

\section{Kaynaklar}

1. Ernster L, Schatz G. Mitochondria: A Historical Review. J Cell Biol. 1981;91:227-55. [CrossRef]

2. West AP, Shadel GS, Ghosh S. Mitochondria in Innate Immune Responses. Nat Rev Immunol 2011;11:389-492. [CrossRef]

3. Anzell AR, Maizy R, Przyklenk K, Sanderson TH. Mitochondrial Quality Control and Disease: Insights into Ischemia-Reperfusion Injury. Mol Neurobiol 2018;55:2547-64. [CrossRef]

4. Aksu E. Megakoniyal Konjenital Müsküler Distrofi Hastalığında Mitokondri Dinamiğinin İncelenmesi. (Yayınlanmamış tez) Hacettepe Üniversitesi, Ankara, 2017. http://www.openaccess.hacettepe. edu.tr:8080/xmlui/bitstream/handle/11655/3727/10156756. pdf? sequence $=3$ \&isAllowed $=y$

5. Pieczenik SR ve Neustadt J. Mitochondrial Dysfunction and Molecular Pathways of Disease. Exp Mol Pathol 2007;83:84-92. [CrossRef]

6. Weinberg SE, Sena LA, Chandel NS. Mitochondria in Regulation of Innate and Adaptive Immunity. Immunity 2015;17:406-17. [CrossRef]

7. West AP, Shadel GS. Mitochondrial DNA in Innate Immune Responses and Inflammatory Pathology. Nat Rev Immunol 2017;17:363-75. [CrossRef] engellenmesi vb.) önerilmesini sağlamıştır (46). Gerek otoimmün, gerekse sekonder inflamasyon bulgularının saptanmış olduğu tüm hastalıklarda ccf-mtDNA'nın patogeneze etki eden potansiyel bir faktör olup olmadığı halen bilinmemektedir. Evrimsel geçmişi olan bu organel DNA'sının doğal bağışıklık sistemine detaylı etkilerini ve hastalıkların tedavisine yön verebilme potansiyelini anlayabilmek için yapılan çalışmalar günümüzde halen devam etmektedir.

8. Luft R. The Development of Mitochondrial Medicine. Proc Natl Acad Sci USA 1994;91:8731-8. [CrossRef]

9. Endo T ve Yamano K. Multiple Pathways for Mitochondrial Protein Traffic. Biol Chem 2009;390:8:723-30. [CrossRef]

10. Cole LW. The Evolution of Per-cell Organelle Number. Front. Cell Dev. Biol. 2016;4:85. [CrossRef]

11. Wiesner RJ, Ruegg JC, Morano I. Counting Target Molecules by Exponential Polymerase Chain Reaction: Copy Number of Mitochondrial DNA in Rat Tissues. Biochem Biophys Res Commun 1992;183:553-9. [CrossRef]

12. Bonawitz ND, Clayton DA, Shadel GS. Initiation and beyond: Multiple Functions of the Human Mitochondrial Transcription Machinery. Molecular Cell. 2006;24:813-25. [CrossRef]

13. Wallace DC. A Mitochondrial Paradigm of Metabolic and Degenerative Diseases, Aging, and Cancer: A Dawn for Evolutionary Medicine. Annu. Rev. Genet 2005;39:359-407. [CrossRef]

14. O'Rourke TW, Doudican NA, Mackereth MD, Doetsch PW, Shadel GS. Mitochondrial Dysfunction Due to Oxidative Mitochondrial DNA Damage is Reduced Through Cooperative Actions of Diverse Proteins. Mol. Cell. Biol. 2002;22:4086-93. [CrossRef] 
15. Kang $D$ ve Hamasaki N. Alterations of Mitochondrial DNA in Common Diseases and Disease States: Aging, Neurodegeneration, Heart Failure, Diabetes and Cancer. Curr Med Chem 2005;4:429-41. [CrossRef]

16. Singer TP ve Ramsay RR. Mechanism of the Neurotoxicity of MPTP. An Update. FEBS Lett.1990;274:1-8. [CrossRef]

17. Bandy B ve Davison AJ. Mitochondrial Mutations May Increase Oxidative Stress: Implications for Carcinogenesis and Aging? Free Radical. Biol. Med. 1990;8:523-39. [CrossRef]

18. Hemmi H, Takeuchi O, Kawai T, Kaisho T, Sato S, Sanjo H, et al. A Tolllike Receptor Recognizes Bacterial DNA. Nature 2000;408:740-45. [CrossRef]

19. Barbalat R, Ewald SE, Mouchess ML, Barton GM. Nucleic Acid Recognition by the Innate Immune System. Annu Rev Immunol 2011;29:185-214. [CrossRef]

20. Hong EE, Okitsu CY, Smith AD, Hsieh CL. Regionally Specific and Genome-Wide Analyses Conclusively Demonstrate the Absence of $\mathrm{CpG}$ methylation in Human Mitochondrial DNA. Mol. Cell. Biol 2013;33:2683-90. [CrossRef]

21. Bellizzi D, D'Aquila P, Scafone T, Giardano M, Riso V, Riccio A, et al. The Control Region of Mitochondrial DNA Shows an Unusual CpG and Non-CpG Methylation Pattern. DNA Research. An International Journal for Rapid Publication of Reports on Genes and Genomes. 2013;20:537-47. [CrossRef]

22. Liu B, Du Q, Chen L, Fu G, Li S, Fu L, et al. CpG Methylation Patterns of Human Mitochondrial DNA. Sci Rep 2016;6:23421. [CrossRef]

23. Jiang WW. Increased Mitochondrial DNA Content in Saliva Associated with Head and Neck Cancer. Clini Cancer Res, 2005;11:2486-91. [CrossRef]

24. Ho PWL, Pang WF, Luk CCW, Ng JKC, Chow KM, Kwan BCH, et al. Urinary Mitochondrial DNA Level as a Biomarker of Acute Kidney Injury Severity. Kidney Dis 2017;3:78-83 [CrossRef]

25. Hajizadeh S, DeGroot J, TeKoppele JM, Tarkowski A, Collins LV. Extracellular Mitochondrial DNA and Oxidatively Damaged DNA in Synovial Fluid of Patients with Rheumatoid Arthritis. Arthritis Res Ther 2003;5:R234-40. [CrossRef]

26. Pyle A, Anugrha $\mathrm{H}$, Kurzawa-Akanbi M, Yarnall A, Burn D, Hudson G. Reduced Mitochondrial DNA Copy Number is a Biomarker of Parkinson's Disease. Neurobiol Aging 2016;38:216.e7-216.e10. [CrossRef]

27. Zhang Q, Raoof M, Chen Y, Sumi Y, Sursal T, Junger W et al. Circulating Mitochondrial DAMPs Cause Inflammatory Responses to Injury. Nature 2010;464:104-7. [CrossRef]

28. Nakahira K, Haspel JA, Rathinam VA, Lee SJ, Dolinay T, Lam HC et al. Autophagy Proteins Regulate Innate Immune Responses by Inhibiting the Release of Mitochondrial DNA Mediated by the NALP3 Inflammasome. Nat. Immunol 2011;12:222-30 [CrossRef]

29. Riley JS, Quarato G, Cloix C, Lopez J, O'Prey J, Pearson M et al. Mitochondrial Inner Membrane Permeabilization Enables mtDNA Release During Apoptosis. EMBO J. 2018;37:e99298 [CrossRef]

30. Thurairajah K, Briggs GD, Balogh ZJ. The Source of Cell-free Mitochondrial DNA in Trauma and Potential Therapeutic Strategies. Eur J Trauma Emerg Surg 2018;44:325-34. [CrossRef]

31. Lichtenstein AV, Melkonyan HS, TomeI LD, Umansky SR. Circulating Nucleic Acids and Apoptosis. Ann NY Acad Sci. 2006;945:239-49. [CrossRef]

32. Chiu RW, Chan LY, Lam NY, Tsui NB, Ng EK, Rainer TH, et al. Quantitative Analysis of Circulating Mitochondrial DNA in Plasma. Clin Chem 2003;49:719-26. [CrossRef]

33. Chandrananda D, Thorne NP, Bahlo M. High-Resolution Characterization of Sequence Signatures Due to Non-random Cleavage of Cell-free DNA. BMC Med Genomics 2015;8:29. [CrossRef]
34. Wilkins HM, Weidling IW, Ji Y, Swerdlow RH. Mitochondriaderived Damage-Associated Molecular Patterns in Neurodegeneration. Front Immunol. 2017;8:508. [CrossRef]

35. Caielli S, Athale S, Domic B, Murat E, Chandra M, Banchereau R, et al. Oxidized Mitochondrial Nucleoids Released by Neutrophils Drive Type I Interferon Production in Human Lupus. J Exp Med 2016;213:697-713. [CrossRef]

36. García N, García JJ, Correa F, Chávez E. The Permeability Transition Pore as a Pathway for the Release of Mitochondrial DNA. Life Sci. 2005;76:2873-80. [CrossRef]

37. García N ve Chávez E. Mitochondrial DNA Fragments Released Through the Permeability Transition Pore Correspond to Specific Gene Size. Life Sci. 2007;81:1160-6. [CrossRef]

38. Patrushev M, Kasymov V, Patrusheva V, Ushakova T, Gogvadze V, Gaziev A. Mitochondrial Permeability Transition Triggers the Release of mtDNA Fragments. Cell. Mol. Life Sci. 2004;61:3100-3 [CrossRef]

39. Gyorgy B, Szabo TG, Pasztoi M, Pal Z, Misjak P, Aradi B, et al. Membrane Vesicles, Current State-of-the-Art: Emerging Role of Extracellular Vesicles. Cell Mol Life Sci 2011;68:2667-88. [CrossRef]

40. Picca A, Lezza AMS, Leeuwenburgh C, Pesce V, Calvani R, Landi F, et al. Fueling Inflamm-Aging Through Mitochondrial Dysfunction: Mechanisms and Molecular Targets. Int J Mol Sci 2017;18:pii:E933. [CrossRef]

41. Nakahira K, Hisata S, Choi AMK. The Roles of Mitochondrial DamageAssociated Molecular Patterns in Diseases. Antioxid Redox Signal 2015;23:1329-50. [CrossRef]

42. Chunju F, Xiawei W, Yuquan W. Mitochondrial DNA in the Regulation of Innate Immune Responses. Protein Cell 2016;7:11 6. [CrossRef]

43. Wei X, Shao B, He Z, Ye T, Luo M, Sang Y, et al. Cationic Nanocarriers Induce Cell Necrosis Through Impairment of $\mathrm{Na}+/ \mathrm{K}+-$ ATPase and Cause Subsequent Inflammatory Response. Cell Res. 2015;25:23753. [CrossRef]

44. Julian MW, Shao G, VanGundy ZC, Papenfuss TL, Crouser ED. Mitochondrial Transcription Factor A, an Endogenous Danger Signal, Promotes TNFa Release via RAGE- and TLR9- Responsive Plasmacytoid Dendritic Cells. PLoS One 2013;8:e72354. [CrossRef]

45. Shimada K, Crother TR, Karlin J, Dagvadorj J, Chiba N, Chen S, et al. Oxidized Mitochondrial DNA Activates the NLRP3 Inflammasome During Apoptosis. Immunity 2012;36:401-14. [CrossRef]

46. Boyapati RK, Tamborska A, Doward DA, Ho GT. Advances in the Understanding of Mitochondrial DNA as a Pathogenic Factor in Inflammatory Diseases. F1000Res. 2017;6:169. [CrossRef]

47. West AP, Khoury-Hanold W, Staron M, Tal MC, Pineda CM, Lang SM, et al. Mitochondrial DNA Stress Primes the Antiviral Innate Immune Response. Nature 2015; 520:553-7. [CrossRef]

48. Gao D, Wu J, Wu YT, Du F, Aroh C, Yan N, et al. Cyclic GMP-AMP Synthase is an Innate Immune Sensor of HIV and Other Retroviruses. Science 2013:341;903-6. [CrossRef]

49. Rongvaux A, Willinger T, Martinek J, Strowing T, Gearty SV, Teichmann LL, et al. Apoptotic Caspases Prevent the Induction of Type I Interferons by Mitochondrial DNA. Cell 2014;159:1563-77. [CrossRef]

50. White MJ, McArthur K, Metcalf D, Lane RM, Cambier JC, Herold MJ, et al. Apoptotic Caspases Suppress mtDNA-induced STING-Mediated Type I IFN Production. Cell 2014;159:1549-62. [CrossRef]

51. Wang H, Li T, Chen S, Gu Y, Ye S. Neutrophil Extracellular Trap Mitochondrial DNA and Its Autoantibody in Systemic Lupus Erythematosus and A ProofofConcept Trial of Metformin. Arthritis Rheumatol 2015;67:3190-200. [CrossRef] 
52. Lood C, Blanco LP, Purmalek MM, Carmona-Rivera C, De Ravin SS, Smith CK, et al. Neutrophil Extracellular Traps Enriched in Oxidized Mitochondrial DNA are Interferogenic and Contribute to Lupus-like Disease. Nat. Med 2016;22:146-53. [CrossRef]

53. Mcllroy DJ, Jarnicki AG, Au GG, Lott N, Smith DW, Hansbro PM, et al. Mitochondrial DNA Neutrophil Extracellular Traps are Formed After Trauma and Subsequent Surgery. J. Crit Care 2014;29:1133.e1-5. [CrossRef]

54. Zhang B, Asadi S, Weng Z, Sismanopoulos N, Theoharides TC. Stimulated Human Mast Cells Secrete Mitochondrial Components That Have Autocrine and Paracrine Inflammatory Actions. PLoS One 2012;7:12,e49767. [CrossRef]
55. Boudreau LH, Duchez AC, Cloutier N, Soulet D, Martin N, Bollinger $\mathrm{J}$, et al. Platelets Release Mitochondria Serving as Substrate for Bactericidal Group IIA-Secreted Phospholipase A2 to Promote Inflammation. Blood 2014;124: 2173-83. [CrossRef]

56. Diaz LA JR, Bardelli A. Liquid biopsies: Genotyping Circulating Tumor DNA. J Clin Oncol. 2014; 32:579-86. [CrossRef]

57. Elshimali $\mathrm{YI}$, Khaddour $\mathrm{H}$, Sarkissyan $\mathrm{M}, \mathrm{Wu} \mathrm{Y}$, Vadgama JV. The Clinical Utilization of Circulating Cell Free DNA (CCFDNA) in Blood of Cancer Patients. Int J Mol Sci, 2013;14:18925-58. [CrossRef] 